Article

\title{
Sustainable Enterprise Excellence: Attribute-Based Assessment Protocol
}

\author{
Tajammal Hussain ${ }^{1,2, *}$, Rick Edgeman ${ }^{2,3,4}$, Jacob Eskildsen ${ }^{5}{ }^{(0)}$, Alaa Mohamed Shoukry ${ }^{6,7}$ and \\ Showkat Gani ${ }^{8}$ \\ 1 Department of Statistics, COMSATS University Islamabad, Lahore Campus 54000, Pakistan \\ 2 Business Developments \& Technology Department, Aarhus University, 1, 8000 Herning, Denmark; \\ rick.edgeman@usu.edu \\ 3 Management Department, College of Business \& Entrepreneurship, Fort Hays State University, \\ Hays, KS 67601, USA \\ 4 Technology \& Innovation Department, Faculty of Engineering, University of Southern Denmark, 55, \\ 5230 Odense, Denmark \\ 5 Management Department, Aarhus BSS, Aarhus University, 1, 8000 Aarhus, Denmark; \\ eskildsen@mgmt.au.dk \\ 6 Arriyadh Community College, King Saud University, Riyadh 11451, Saudi Arabia; aabdulhamid@ksu.edu.sa \\ 7 KSA Workers University, Cairo 11311, Egypt \\ 8 College of Business Administration, King Saud University, Muzahimiyah 11451, Saudi Arabia; \\ sgani@ksu.edu.sa \\ * Correspondence: tajammal@cuilahore.edu.pk
}

Received: 4 October 2018; Accepted: 31 October 2018; Published: 8 November 2018

\begin{abstract}
This paper is intended to design and provide a reliable and valid measurement instrument to aid organizations that wish to self-assess their performance and positioning relative to sustainable enterprise excellence. Recent research trends in performance excellence, quality management, and organizational sustainability have been directed towards integrated management systems (IMS). Sustainable Enterprise Excellence (SEE) is among these integrated management systems. SEE is undergoing ongoing development and its measurement scale is rudimentary, hence it lacks the more sophisticated sorts of measurement scales often used for organizational self-assessment purposes. A scientific approach is used herein to devise a more comprehensive SEE-oriented organizational assessment against six proposed performance results-oriented domains or constructs: governance and strategy, process implementation, sustainability performance, financial performance, innovation performance, and human capital performance. Each organizational performance construct is to be measured by ten attributes-based items. Maturity scale ratings that range from 0 to 10 reflect organizational performance relative to the associated item and the sum of item ratings across a construct reflects performance within the specific domain, the summation of the six construct scores then yields a measure of the overall organizational performance with respect to SEE. The assessment areas against which organization performance compares poorly suggest opportunities for improvement of associated business processes, the achievement of which will contribute to a sustainable future.
\end{abstract}

Keywords: business excellence; sustainability; governance; process orientation; innovation; scale development; human capital; capacity building

\section{Introduction}

The dynamic nature of businesses, expanding markets, ever-increasing customer awareness, and innovative technologies have a significant role in reshaping the ways organizations do business in 
the modern era. Sustainable Enterprise Excellence (SEE), as proposed by [1] and further developed by [2-7] is an integrated management approach to achieve business excellence. The slogans of quality, wars of survival, branding for a competitive edge, thinking beyond customers' expectations, and proactive business decisions are the hallmarks of the revolutionary changes in organizational approaches towards businesses excellence [8-11]. Thoughtful research has been published in recent decades focusing on: quality management [12,13]; business excellence [14-16]; and organizational sustainability [17-20]. The notions, objectives, key enablers, and ultimate expected outcomes across these different proposed frameworks overlap to a great extent [21-23].

Organizations are generally keen to identify and implement reliable performance improvement strategies. However, not all organizations are successful in this pursuit and literature on business excellence and allied fields suggests there is no sure remedy or shortcut. Business excellence does not happen overnight or accidently. Rather, it results from an integrated, synchronized, and effective use of human, financial, and social resources deployed by the organization $[14,24,25]$.

Business excellence models (BEM) are intended to provide a roadmap that can be adapted by an organization to achieve business excellence $[25,26]$. Comparatively, sustainable enterprise research additionally focuses on devising a mechanism to enhance organizational ability to maintain and excel its business performance in future markets [27-31]. Schaltegger, Hansen [32] explored the evolution of research in business models for sustainability by evaluating the number of proposed business models for sustainability (SBMs), for example, the sustainability business model [18], the sustainability innovation cube [33], business models for relocalisation [34], generative models of social enterprise [35], and industry-level business models for sustainability [36].

An organization's pursuit of excellence is driven by both internal and external factors. Organizational performance is a strong reflection of organizational well-being, effective delivery of products and services, process efficiency and effectiveness, business longevity, and sustainability $[37,38]$. However, for many organizations, sustainability remains a vague concept that requires extensive investment of both financial and non-financial resources to understand and effectively implement it $[39,40]$. The effective adoption of knowledge management strategies can speed up both the understanding and leverage of sustainable system dynamics [41,42].

With the mission of enhancing the understanding of and progress toward sustainable excellence, by building the sound theoretical foundation [1], proposed the Sustainable Enterprise Excellence (SEE) model wherein:

Sustainable enterprise excellence is a consequence of ongoing attainment of balance among the competing and complementary interests of key stakeholder segments. In addition to more commonly noted stakeholder segments such as customers, shareholders, and policy makers, SEE deeply integrates society as an explicit stakeholder and the natural environment as an implicit one. Attainment of such balance increases the likelihood of superior and sustainable competitive positioning and hence long-term enterprise success.

This is accomplished through an integrated approach to organizational design and function emphasising innovation, operational, customer-related, human capital, financial, marketplace, societal, and environmental performance. [4]

The attainment of SEE requires successful and sustainable management for excellence, which delivers an enterprise that is:

- Sustainable to the extent that it creates and maintains economic, ecological, and social value for itself, its stakeholders, society at large, and policy makers;

- Resilient to the extent that it possesses the capacity to self-renew through innovation by adapting its responses to negative shocks and challenges over time;

- Robust to the extent that it is highly resistant or immune to a critical subset of such shocks and challenges; 
- Excellent when its governance, leadership, and strategy, as deployed through people, processes, partnerships, and policies, deliver sustained superior performance and impact in critical enterprise areas such as enterprise human ecology, innovation, financial, social, ecological, enterprise intelligence gathering, analytics, and supply chain management $[3,5]$

SEE provides an organizational framework to perform a self-assessment of an organization's current status (insight) and provide foresight into the changes necessary for the organization to further progress in its pursuit of sustainable excellence. The SEE framework employs six performance domains; however, the development of scale and the validation of measuring the SEE constructs was left to the organization. This paper intends to fill this gap through the development of relevant attribute-based measures and associated reliable scales for each of the domains. The following section discusses each relevant SEE enabler and attribute-based measure.

\section{The Role of Governance and Strategy in Achieving SEE}

The critical dimensions of governance-culture, style, structure, approach, and mechanisms-and performance indicators vary considerably across organizations, nations, and regions depending on prevailing traditions and norms [43-45]. Organizational governance has been addressed in business excellence models and quality awards through the use of leadership as a proxy. There is little consensus on the definition and reliability of its most commonly proposed indicators [43]. Despite being different in formational nature, governance has almost universally agreed upon the expected features: transparency, fairness, accountability, effectiveness, and efficiency [46,47]. There is a strong association between organizational business strategies and the governance mechanism where organizations with a more aggressive strategy generally have more results-oriented governance [48]. Although most organizations adopt a single primary strategy, others tend to devise a limited portfolio of collectively dominant strategies [49].

In conceptualizing the governance and strategy construct for SEE, [50] demonstrated that through the integration of E3 (efficient, effective, and ethical) governance with 3E (equitable, ecological, and economic) strategy, organizations could achieve better performance in 3P (People, Profit, Planet) performance domains. Table 1 provides the proposed subscale for governance and strategy; the scale is based on attributes and associated measurement items.

Table 1. Attributes-based measures of governance and strategy.

\begin{aligned} \hline Attribute & Attribute-Based Measures \\ \hline Fairness and transparency & To what extent is governance fair and transparent? \\ Effectiveness & To what extent is governance accountable? \\ Command and control & To what extent is governance of command and control effective? \\ Trustfulness & To what extent do employees trust in governance capability? \\ Competence & To what extent has leadership been successful in managing the organization? \\ Initiating & To what extent is leadership proactive on strategic fronts? \\ Harmony & What is the extent of agreement between the organization's strategy and implementation? \\ Aggressiveness & To what extent is organizational strategy aggressive? \\ Corruption free & To what extent is organizational leadership free of corruption? \\ Effectiveness & To what extent does leadership deliver effective governance? \end{aligned}

\subsection{SEE and Process Execution and Implementation}

In competitive business environments, change is the phenomenon that drives the organization to adopt new and better business strategies and to align and synchronize business processes. Strategically, organizations secure their competitive edge by developing efficient and cost-effective business processes rather than through the more frequent introduction of new product-lines. The results of individual business processes are determinants of organizational performance, competitiveness, and sustainability [51]. Performance management emphasizes the coordination of processes that together form systems, with system success determined by purposeful alignment, synergistic functionality, operative measurement, and effective control. This requires a clear identification and understanding 
of the purpose, function, and execution of each process together with the relevant performance measurement [52-54]. A business process lifecycle may be explained effectively through its division into six main components: modelling, deployment, optimization, management, culture, and structure (for detail, see: [55]). Table 2 provides the proposed subscale for process implementation and execution; the scale is based on representative attributes and associated measurement items.

Table 2. Attributes-based measures of process implementation and execution.

\begin{aligned} & \hline \multicolumn{1}{c}{ Attribute } \multicolumn{1}{c}{ Attribute-Based Measures } \\ & \hline Job description $\begin{array}{l}\text { What is the extent to which standard operating procedures (SOPs) for all major jobs/tasks } \\ \text { exist and are used? }\end{array} \\ &$\hline Process clarity $\begin{array}{l}\text { That degree of clarity do the workers responsible for a process have concerning its inputs } \\ \text { critical processes? }\end{array} \\ &$\hline Process implementation To what extent are organizational processes implemented and followed as intended? \\ & \hline Representation To what extent are useful measurable performance parameters employed? \\ & \hline Alignment What is the extent of alignment among key organizational processes? \\ & \hline Monitoring and controlling $\begin{array}{l}\text { To what extent are effective organizational process monitoring and control } \\ \text { mechanisms used? }\end{array} \\ &$\hline Creative problem-solving To what extent is human ecology encouraged to engage in creative problem-solving? \\ & \hline Acceptability To what extent do employees have positive attitudes towards organizational processes? \\ & \hline\end{aligned}

\subsection{SEE and Financial Performance}

A significant amount of literature on performance management reports financial performance as a proxy for overall firm performance [56,57]. Mostly, organizations face challenges in managing their financial resources effectively due to poor organizational performance on associated fronts [58,59]. Although organizations must address both economic and social results to gauge their performance, establishing and simultaneously pursuing complementary goals for both is challenging [60-63]. The devastating impact of recent financial crises on global and regional economies has raised questions concerning the aptness and effectiveness of financial models in the face of modern challenges. An improved response to such challenges demands the derivation of more reliable financial information systems and management practices $[64,65]$. Corporate financial performance is a reflection of product and service quality, the effectiveness of the organization's business approach, collective well-being, and the ability to remain sustainable and competitive [66]. Table 3 provides the proposed subscale for financial performance and is based on relevant financial attributes and associated measurement items.

Table 3. Attributes-based measures of financial performance results.

\begin{aligned} & \hline \multicolumn{1}{r}{ Attribute } \multicolumn{1}{c}{ Attribute-Based Measures } \\ & \hline Reliability To what extent are the organization's financial reports reliable? \\ & Trust To what extent is the organization trusted by its stakeholders? \\ & \hline Availability To what extent do insufficient financial resources hinder organizational growth? \\ & \hline erformance To what extent is current financial performance alarming? \\ & \hline Expectancy To what extent is the organization's future perceived as financially healthy? \\ & \hline Accountability To what extent is financial accountability assured? \\ & \hline Resilience To what extent is the organization resilient to financial shocks? \\ & \hline Solvency $\begin{array}{l}\text { To what extent does the organization have sufficient financial resources to withstand a } \\ \text { more prolonged economic crisis? }\end{array} \\ &$\hline Diversification $\begin{array}{l}\text { To what extent has the organization diversified its profit-generating products, services, } \\ \text { and activities? }\end{array} \\ &$\hline\end{aligned}




\subsection{SEE and Sustainability Performance}

The rise to prominence of the environmental and social concerns of sustainability over the last few decades has drawn significant attention to the jointly optimal deployment of natural, intellectual, and financial resources $[40,67,68]$. This thinking reflects the approach to sustainable development first espoused in the landmark report "Our Common Future" [69] as well as the traditional beliefs held by many cultures of meeting the needs of the present generation while concurrently acting as stewards of resources for generations not yet born. Corporate Social and Environmental Responsibility (CSER) reflects the effort organizations exert to contribute to global sustainability [70]. As integral parts of society, organizations are ethically bound to use their resources in ways that contribute to social, environmental, and organizational sustainability, with the 10R approach ( for detail, see: [71]), operational learning (for detail, see: [72]), and integrative modelling [for detail, see:37] providing examples of viable strategies for pursuing these goals.

Successful organizational sustainability efforts demand passionate involvement of leadership in the process of sensing, bringing, promoting, and appreciating the changes needed to promote a culture characterized by socio-economic and environmental sustainability [17,73]. Future organizational success relies heavily on many factors, including the identification of relevant new business strategies, resource utilization, and the ability to remain viable on economic, social, and environmental fronts [28,74-76]. Edgeman and Eskildsen [1] regard organizational performance in the sustainability domain as an indicator of organizational ability to become and remain sustainably excellent. Table 4 provides a subscale for sustainability performance that is based on attributes and associated measurement items that reflect business sustainability.

Table 4. Attributes-based measures of sustainability performance results.

\begin{aligned} \hline \multicolumn{1}{c}{ Attribute } & \multicolumn{1}{c}{ Attribute-Based Measures } \\ \hline Competitiveness & To what extent does the organization hold an edge over its competitors? \\ \hline Customer expectation & To what extent does the organization have the ability to satisfy customers' future needs? \\ \hline Exploration & To what extent has the organization successfully leveraged market trends? \\ \hline Expansion & To what extent has the organization successfully upgraded processes, products, and services over time? \\ \hline Collaboration & To what extent has the organization succeeded in building strong relationships with its suppliers? \\ \hline Goal orientation & To what extent does the organization successfully balance and align short- and long-term goals? \\ \hline Retention & To what extent has the organization succeeded over time in retaining valuable intellectual resources? \\ \hline Exploitation & To what extent has the organization successfully exploited market opportunities? \\ \hline Assessment & To what extent does the organization have an effective self-assessment mechanism? \end{aligned}

\subsection{SEE and Innovation Performance}

The competitive contexts in which organizations function vary over time, meaning that business strategies, practices, and mind-sets that were successful in prior times should not be regarded as monolithic if an organization is to adapt and prosper when its competitive landscape shifts $[77,78]$. Rapid learning that delivers timely innovation ranks highly among competitive edges exhibited by market leaders [50,79].

This is especially critical for organizations functioning in more uncertain or dynamic environments. In such environments, faster technology or service innovation and advancement drives the agility needed to respond to changing customer expectations [80]. This, in turn, fuels the drive toward sustainable business excellence via the development of new and innovative ways of performing business functions. In this way, organizational sustainability orientations encourage innovation [81,82]. Thus, research and development, technology innovation, business model innovation, and innovation in processes, leadership style, and structure each stimulate advancement toward sustained excellence [83-85]. 
Innovation is the key to organizational development and organizations that do not adapt or revolutionize ways of getting jobs done, managing people, dealing with customers, and governing enterprise risk stagnation or obsolescence [86]. More generally, the sort of innovation sought is social-ecological innovation (SEI) that results from the integration of sustainable innovation with innovation for sustainability. Innovation for sustainability presumes that some portion of the efforts included in organization's innovation portfolio must target social or ecological objectives, whereas sustainable innovation implies that the organization's approach to innovation is regular, routine, rigorous, systematic, and systemic [50]. Better SEI occurs when it is strongly aligned with organizational culture [87]. Strategic relationships between SEI, SEE, and C2C (Cradle-to-Cradle) approaches that recycle or transform end-of-product-life technical and organic components into nutrients for other or next-generation products have been identified and the means for their advancement described (for detail, see: [71]). Table 5 provides a subscale for innovation performance that is based on attributes and associated measurement items.

Table 5. Attributes-based measures of innovation performance results.

\begin{aligned} & \hline \multicolumn{1}{c}{ Attribute } \multicolumn{1}{c}{ Attribute-Based Measures } \\ & \hline Engaging To what extent does the organization encourage employee suggestions of new and innovative business ideas? \\ & Consulting To what extent does the organization engage external consultants for improvements? \\ & Participating To what extent does the organization participate in relevant seminars, conferences, and other similar learning occasions? \\ & Initiating To what extent does the organization implement new ideas? \\ & Innovating To what extent does the organization innovate its business approaches? \\ & Collaborating To what extent does the organization collaborate with industry leaders to learn new ways of business? \\ & Launching To what extent does the organization have a systematic mechanism to launch innovative ideas? \\ & Promoting To what extent does the organization want to be known as an innovative organization? \\ & Excelling To what extent does the organization utilize innovation as a strategic tool for gaining a competitive edge? \\ & Caring To what extent does the organization have a mechanism to collect customer voices? \\ & \hline\end{aligned}

\subsection{SEE and Human Capital Performance}

The strategic significance of an organization's human capital for competitiveness, business performance, and progress toward SEE and hence a sustainable future is widely acknowledged [88-90], with development and engagement being especially central [91,92]. The effective integration of business excellence, sustainable development, and continuous improvement required to prepare organizations call for the alignment of general strategic planning and human resource strategies $[93,94]$. This, in turn, improves the organization's ability to combat challenges to its survival through strategically and tactically improved competitive positioning.

The adoption of state-of-the-art human resource management practices has the potential to provide an enhanced work environment and quality of work life - two factors that are essential to high levels of employee motivation, engagement, loyalty, and commitment to organizational purpose [95]. The linkage of employee development efforts with employee intentions and behaviors and, in turn, healthy organizational cultures is well-established [96,97].

An organization is enriched when its human capital offers diverse individual attitudes, behaviors, capabilities, and actions. At the same time, such diversity creates management challenges that demand careful attention with respect to both individual and team dynamics (for detail, see: [98]). The ability of organizations to attract competent and diverse talent is the foremost enabler of human capital capacity building and is strongly related internally to the work environment and externally to an organization's market reputation. Optimizing the environment in which the organization's human ecology performs and the results of that performance requires an effective human resource management system that follows a highly strategic approach to the improvement of work, compensation, and career enrichment and advancement and, concurrently, a healthy work-life balance.

The SEE Model regards organizational ability for the effective and efficient management of human capital as a key indicator of the organization's propensity toward sustainable enterprise excellence. Table 6 provides a subscale for human capital performance that explores the extent to which the organization successfully capitalizes its available human ecology. 
Table 6. Attributes-based measures of human capital performance results.

\begin{aligned} & \hline \multicolumn{1}{c}{ Attribute } \multicolumn{1}{c}{ Attribute-Based Measures } \\ & \hline Attraction To what extent has the organization succeeded in attracting talented intellectual capital? \\ & \hline Employment To what extent has the organization succeeded in hiring valuable human capital? \\ & \hline Retention To what extent does the organization successfully retain talented human capital? \\ & \hline Motivation To what extent does the organization's human ecology consistently deliver best performance? \\ & \hline Appraisal $\begin{array}{l}\text { To what extent has the organization implemented a fair, transparent, and adaptive performance } \\ \text { appraisal system? }\end{array} \\ &$\hline Resolution To what extent does the organization successfully resolve job-related grievances? \\ & \hline Promotion To what extent does the organization provide clear and upward employee career paths? \\ & \hline Reputation To what extent has the organization earned a positive reputation as a leading employer? \\ & \hline Compensation To what extent does the organization provide competitive compensation? \\ & \hline $\begin{array}{l}\text { To what extent has the organization succeeded in building its human ecology capacity and to } \\ \text { what extent does it have a strategic plan in place to ensure ongoing improvement in this area? }\end{array} \\ &$\hline\end{aligned}

\section{Sustainable Enterprise Excellence Scale (SEES) Summary}

The SEE assessment scale is based on six performance domains, as suggested by [1]: strategy and governance (SAG); process implementation and execution (PIE); financial performance results (FPR); sustainability performance results (SPR); innovation performance results (IPR); and human capital performance results (HCR). The constructs are essential for measuring the ability of an organization to achieve and sustain excellence. Each performance domain is represented by a construct composed of ten items, with each item being based on an associated attribute. Each item is assigned a score from 0 to 10 that depends upon the extent to which the organization excels with respect to the item attribute. Furthermore, scores of all the given items in a construct are summed to yield a total score for each construct. Finally, a summation of all six construct subtotals will provide a SEE score of the investigated organization that can range from 0 to 600, with higher scores indicating greater overall progress toward SEE.

Mathematically, this leads to the following formulation. Let $\mathrm{X}_{i j}$ be the score of the $i$ th attribute for the $j$ th construct, then $0 \leq X_{i j} \leq 10$. The score of the $i$ th construct can be represented by $S_{i}$, where $S_{i}=\sum X_{j}$, such that $0 \leq S_{i} \leq 60$. Finally, if the overall SEE score of the $k$ th organization is represented by $\mathrm{SEE}_{k}$, then $\mathrm{SEE}_{k}=\sum \mathrm{S}_{i}$, such that $0 \leq \mathrm{SEE}_{k} \leq 600$.

A maximum score of 600 is expected for the organization believed to be excellent within all six performance domains provided that all constructs are weighted equally. However, interested organizations may determine priorities based on contextual facts by assigning relative weights, $\mathrm{W}_{i}$, to each construct. If relative weights are assigned, then $\mathrm{SEE}_{k}=\sum \mathrm{W}_{i} \mathrm{~S}_{i}$, where $0 \leq \mathrm{W}_{i} \leq 1$, while $\left(\mathrm{W}_{\mathrm{GAS}}+\mathrm{W}_{\mathrm{PEI}}+\mathrm{W}_{\mathrm{FPR}}+\mathrm{W}_{\mathrm{SPR}}+\mathrm{W}_{\mathrm{IPR}}+\mathrm{W}_{\mathrm{HCR}}=1\right)$.

One simple procedure for assigning weights can be derived by asking an informed organizational representative or team of representatives to rank the six constructs from 1 to 6 in terms of priority without assigning duplicate ranks to any constructs, and with higher ranks signifying greater importance.

If a team from the organization is involved in assigning importance rankings, then the nominal group technique (NGT) can be used to derive a proxy ranking representing the collective wisdom of the team [99]. In using the NGT, the rank total $\left(\mathrm{R}_{i}\right)$ for each construct is first attained by adding ranks assigned by team members, from which the weight $\left(\mathrm{W}_{i}\right)$ of each construct can be calculated as $\mathrm{W}_{i}=\frac{\mathrm{R}_{i}}{\sum \mathrm{R}_{i}}$ as $i=1,2, \ldots, 6$. A similar approach can, if desirable, be applied within each construct to differentially weight the associated 10 items. The weight assignment technique can be beneficial in customizing the SEE assessment according to organizational or sectoral preferences and contextual realities. Figure 1 portrays the proposed SEE assessment approach where, for the sake of simplicity, each construct is equally weighted and, within each construct, each assessed item is equally weighted. 


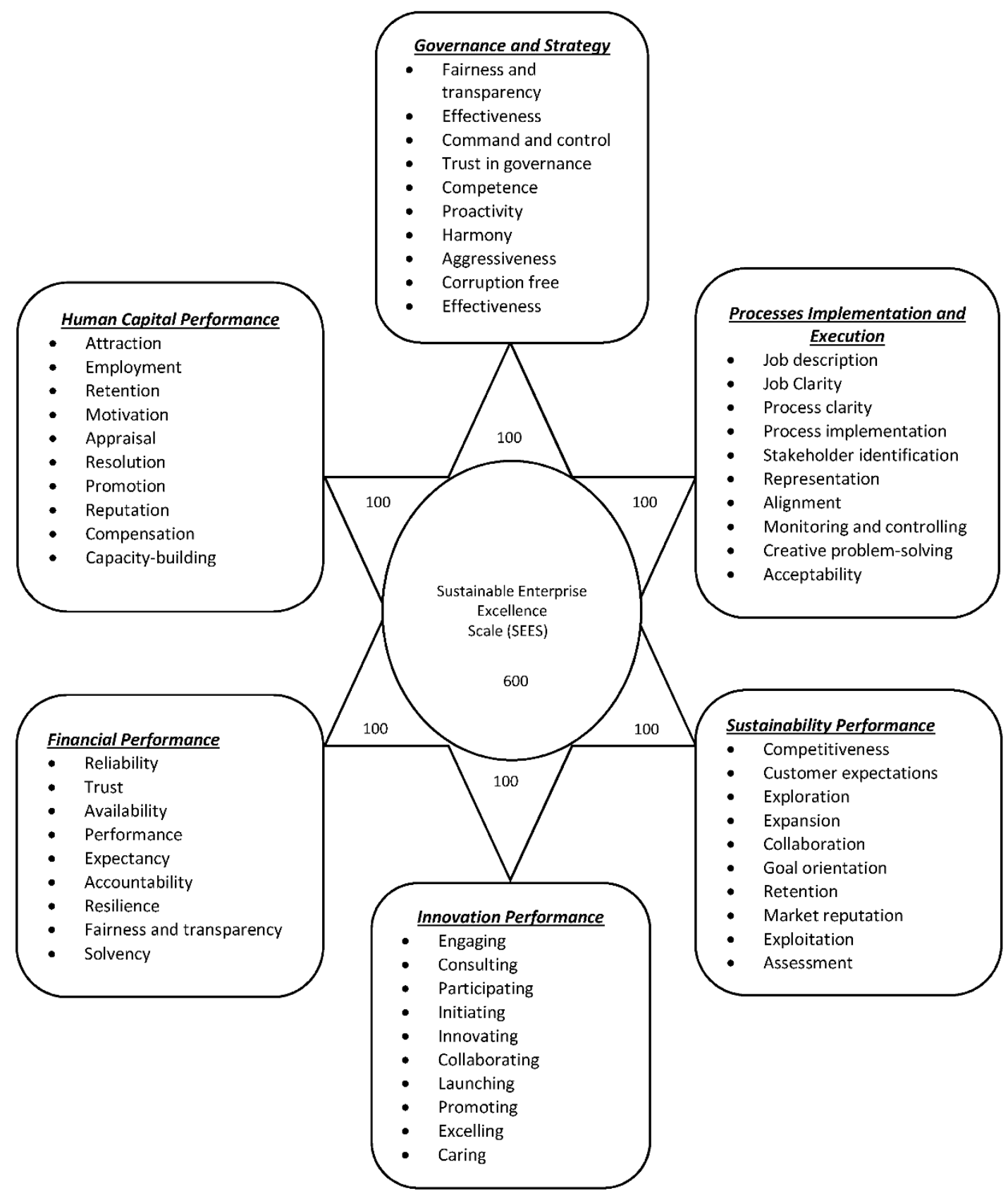

Figure 1. Sustainable Enterprise Excellence Scale (SEES).

\section{Conclusions}

This article presented a quantitative measurement scale for the Sustainable Enterprise Excellence (SEE) model proposed by [1]. The research journey of business excellence has a long history but with different nomenclatures in different times, which include performance excellence, organizational excellence, enterprise excellence, and operational excellence. Its roots can be traced to Taylorism as it was developed near the beginning of the twentieth century. The evolving field benefited greatly from Japanese Statistical Quality Control (SQC), British quality standards, ISO quality standards, business excellence models (BEM), Corporate Social and Environmental Responsibility (CSER), and the field of sustainability. A sophisticated and well-balanced integration of these intellectual knowledge-based sources emerged as the theoretical framework of Sustainable Business Excellence (SEE). Conceptually, the SEE approach is grounded in six constructs, namely: (I) governance and strategy; (II) process execution and implementation; (III) sustainability performance; (IV) financial 
performance; (V) innovation performance; and (VI) human capital performance. This study provides organizations with a measurement scale that can be used to evaluate their performance against the SEE assessment criteria.

It is suggested herein that organizational governance and strategic standing be measured through ten items: (i) fairness and transparency; (ii) effectiveness; (iii) command and control; (iv) trustfulness; (v) competence; (vi) initiating; (vii) harmony; (viii) aggressiveness; (ix) corruption free; and ( $\mathrm{x}$ ) effectiveness. Ten measurements are proposed to assess organizational achievements on the process execution and implementation fronts: (i) job description; (ii) job clarity; (iii) process clarity; (iv) process implementation; (v) stakeholder identification; (vi) representation; (vii) alignment; (viii) monitoring and controlling; (ix) creative problem-solving; (x) and acceptability. For the measurement of organizational financial behavior, ten attributes were proposed herein: (i) reliability; (ii) trust; (iii) availability; (iv) performance; (v) expectancy; (vi) accountability; (vii) resilience; (viii) fairness and transparency; (ix) solvency; and (x) diversification. Organizational business excellence is significantly associated with the organization's ability to remain sustainable on socio-economic fronts. To measure organizational sustainability performance, ten attributes were proposed herein: (i) competitiveness; (ii) customer expectation; (iii) exploration; (iv) expansion; (v) collaboration; (vi) goal orientation; (vii) retention; (viii) market reputation; (ix) exploitation; and $(\mathrm{x})$ assessment. Organizations have always been exposed to severe and persistent challenges to be innovative for the sake of survival. To assess how effectively and efficiently an organization delivers on this front, ten attributes were proposed herein: (i) engaging; (ii) consulting; (iii) participating; (iv) initiating; (v) innovating; (vi) collaborating; (vii) launching; (viii) promoting; (ix) excelling; and (x) caring. Human capital is the most valuable asset for organizations and managing it properly is essential to achieving business excellence. To assess organizational performance in managing human capital, ten attributes were proposed herein: (i) attraction; (ii) employment; (iii) retention; (iv) motivation; (v) appraisal; (vi) resolution; (vii) promotion; (viii) reputation; (ix) compensation; and $(\mathrm{x})$ capacity building.

The proposed measurement scale has the potential to be highly beneficial to organizations willing to measure and gauge their business processes for sustainable excellence in rigorously competitive markets. The assessment approach provided herein can also be used as a self-assessment tool by organizations before submitting to an independent third-party external assessment or audit for quality certification or process validation purposes. SEE could prove more effective and add more value if adopted and exercised considering the approach proposed by [100]. Future research focused on SEE could take multiple directions, including the development of means of measurement such as maturity indices for the items associated with each of the six constructs and, as a natural evolution, the establishment of the statistical validity and reliability of the proposed scale through a field survey. The proposed framework needs to be validated using real-time data to enhance its application to industrial stakeholders' concerns in relation to sustainable business solutions.

Author Contributions: Conceptualization, T.H., R.E. and J.E.; supervision, R.E., J.E.; writing-original draft preparation, T.H.; writing — review and editing, R.E., A.M.S. and S.G.; funding acquisition, A.M.S. and S.G.

Funding: The authors extend their appreciation to the Deanship of Scientific Research at King Saud University for funding this work through research group no. RG-1437-027.

Conflicts of Interest: The authors declare no conflicts of interest.

\section{References}

1. Edgeman, R.; Eskildsen, J. Modeling and assessing sustainable enterprise excellence. Bus. Strategy Environ. 2014, 23, 173-187. [CrossRef]

2. Edgeman, R.; Williams, A.J. Enterprise self-assessment analytics for sustainability, resilience and robustness. TQM J. 2014, 26, 368-381. [CrossRef]

3. Edgeman, R. Strategic resistance for sustaining enterprise relevance: A paradigm for sustainable enterprise excellence, resilience and robustness. Int. J. Prod. Perform. Manag. 2015, 64, 318-333. [CrossRef] 
4. Edgeman, R. Performance Management and Enterprise Excellence through Sustainable Business Models. In Sustainable Business Models; Springer: Berlin, Germay, 2019; pp. 317-359.

5. Edgeman, R.; Eskildsen, J.; Neely, A. Translating triple top line strategy into triple bottom line performance. Meas. Bus. Excell. 2015, 19. [CrossRef]

6. Edgeman, R.; Neely, A.; Eskildsen, J. Paths to sustainable enterprise excellence. J. Model. Manag. 2016, 11, 858-868. [CrossRef]

7. Edgeman, R.; Wu, Z. Anthropocene Age Wicked Challenges: Yin, Yang and Sustainable Enterprise Excellence. In Research in the Decision Sciences for Innovations in Global Supply Chain Networks; Pearson Education Australia: Melbourne, Australia, 2015; pp. 273-294.

8. Russell, S. Business excellence: From outside in or inside out? Total Qual. Manag. 1999, 10, 697-703. [CrossRef]

9. Seghezzi, H.D. Business excellence: What is to be done? Total Qual. Manag. 2001, 12, 861-866. [CrossRef]

10. Gobel-Kobialka, S. Reaching Business Excellence Through Sound People Management. Eur. J. Work. Organ. Psychol. 1998, 7, 549-557. [CrossRef]

11. Haim, K. Business Domain Modeling. In Encyclopedia of Software Engineering; Taylor \& Francis: Andover, UK, 2010; pp. 131-141.

12. Christie, M.; Grunefeld, H.; Thibautt, G. Modelling quality. Eur. J. Eng. Educ. 2001, 26, 441-450. [CrossRef]

13. Dahlgaard, J.J.; Chen, C.-K.; Jang, J.-Y.; Banegas, L.A.; Dahlgaard-Park, S.M. Business excellence models: Limitations, reflections and further development. Total. Qual. Manag. Bus. Excell. 2013, 24, 519-538. [CrossRef]

14. Aras, G.; Crowther, D. Sustaining business excellence. Total. Qual. Manag. Bus. Excell. 2010, 21, 565-576. [CrossRef]

15. Asif, M.; Gouthier, M.H.J. What service excellence can learn from business excellence models. Total. Qual. Manag. Bus. Excell. 2014, 25, 511-531. [CrossRef]

16. Kanji, G.K. Forces of excellence in Kanji's Business Excellence Model. Total Qual. Manag. 2001, 12, $259-272$. [CrossRef]

17. De Matos, J.A.; Clegg, S.R. Sustainability and Organizational Change. J. Chang. Manag. 2013, 13, $382-386$. [CrossRef]

18. Stubbs, W.; Cocklin, C. Conceptualizing a "sustainability business model". Organ. Environ. 2008, 21, $103-127$. [CrossRef]

19. Abdelkafi, N.; Täuscher, K. Business Models for Sustainability from a System Dynamics Perspective. Organ. Environ. 2016, 29, 74-96. [CrossRef]

20. Bocken, N.M.; Short, S.W.; Rana, P.; Evans, S. A literature and practice review to develop sustainable business model archetypes. J. Clean. Prod. 2014, 65, 42-56. [CrossRef]

21. Talwar, B. Comparative study of core values of excellence models vis-à-vis human values. Meas. Bus. Excell. 2009, 13, 34-46. [CrossRef]

22. Lüdeke-Freund, F.; Carroux, S.; Joyce, A.; Massa, L.; Breuer, H. The sustainable business model pattern taxonomy-45 patterns to support sustainability-oriented business model innovation. Sustain. Prod. Consum. 2018, 15, 145-162. [CrossRef]

23. Schoormann, T.; Kaufhold, A.; Behrens, D.; Knackstedt, R. Towards a typology of approaches for sustainability-oriented business model evaluation. In Proceedings of the 21st International Conference on Business Information Systems, Berlin, Germany, 18-20 July 2018; Volume 320, pp. 58-70.

24. Abdullah, M.; Hamid, M.R.A.; Mustafa, Z.; Husain, N.; Idris, F.; Suradi, N.R.M.; Ismail, W.R. Value-based total performance excellence model: A conceptual framework for organisations. Total Qual. Manag. Bus. Excell. 2012, 23, 557-572. [CrossRef]

25. Doeleman, H.J.; ten Have, S.; Ahaus, C.T.B. Empirical evidence on applying the European Foundation for Quality Management Excellence Model, a literature review. Total. Qual. Manag. Bus. Excell. 2014, 25, 439-460. [CrossRef]

26. Cheng, L.-Y.; Wen, D.-C.; Jiang, H.-C. The performance excellence model in construction enterprises: An application study with modelling and analysis. Constr. Manag. Econ. 2014, 32, 1078-1092. [CrossRef]

27. Bäckstrand, K.; Kronsell, A.; Söderholm, P. Organisational challenges to sustainable development. Environ. Polit. 1996, 5, 209-230. [CrossRef] 
28. Jones, M.L. Sustainable organizational capacity building: Is organizational learning a key? Int. J. Hum. Resour. Manag. 2001, 12, 91-98. [CrossRef]

29. Joseph, F.; Alan, D.H. Sustainability and Sustainable Development. In Encyclopedia of Natural Resources: Land; Taylor \& Francis: Andover, UK, 2014; pp. 497-502.

30. Dentchev, N.; Baumgartner, R.; Dieleman, H.; Jóhannsdóttir, L.; Jonker, J.; Nyberg, T.; van Hoof, B. Embracing the variety of sustainable business models: Social entrepreneurship, corporate intrapreneurship, creativity, innovation, and other approaches to sustainability challenges. J. Clean. Prod. 2016, 113, 1-4. [CrossRef]

31. Rauter, R.; Jonker, J.; Baumgartner, R.J. Going one's own way: Drivers in developing business models for sustainability. J. Clean. Prod. 2017, 140, 144-154. [CrossRef]

32. Schaltegger, S.; Hansen, E.G.; Lüdeke-Freund, F. Business Models for Sustainability: Origins, Present Research, and Future Avenues. Organ. Environ. 2016, 29, 3-10. [CrossRef]

33. Hansen, E.G.; Grosse-Dunker, F.; Reichwald, R. Sustainability innovation cube-A framework to evaluate sustainability-oriented innovations. Int. J. Innov. Manag. 2009, 13, 683-713. [CrossRef]

34. Nieuwenhuis, P.; Wells, P. Business models for relocalisation to deliver sustainability. In The Business of Sustainable Mobility; Routledge: Abingdon, UK, 2017; pp. 92-102.

35. Seelos, C. Theorising and strategising with models: Generative models of social enterprises. Int. J. Entrep. Ventur. 2014, 6, 6-21. [CrossRef]

36. Langenus, M.; Dooms, M. Creating an industry-level business model for sustainability: The case of the European ports industry. J. Clean. Prod. 2018, 195, 949-962. [CrossRef]

37. Fairfield, K.D.; Harmon, J.; Behson, S.J. Influences on the organizational implementation of sustainability: An integrative model. Organ. Manag. J. 2011, 8, 4-20. [CrossRef]

38. García-Bernal, J.; Ramírez-Alesón, M. Increasing the organisational performance benefits of TQM: An approach based on organisational design. Total Qual. Manag. Bus. Excell. 2010, 21, 363-382. [CrossRef]

39. George, C.; Reed, M.G. Operationalising just sustainability: Towards a model for place-based governance. Local Environ. 2017, 22, 1105-1123. [CrossRef]

40. Ghosh, S.; Buckler, L.; Skibniewski, M.J.; Negahban, S.; Kwak, Y.H. Organizational governance to integrate sustainability projects: A case study. Technol. Econ. Dev. Econ. 2014, 20, 1-24. [CrossRef]

41. Thompson, J.P.; Cavaleri, S. Dynamic Knowledge, Organizational Growth, and Sustainability. Int. Stud. Manag. Organ. 2010, 40, 50-60. [CrossRef]

42. Morioka, S.N.; Bolis, I.; Evans, S.; Carvalho, M.M. Transforming sustainability challenges into competitive advantage: Multiple case studies kaleidoscope converging into sustainable business models. J. Clean. Prod. 2018, 167, 723-738. [CrossRef]

43. Andrews, M.; Hay, R.; Myers, J. Can Governance Indicators Make Sense? Towards a New Approach to Sector-Specific Measures of Governance. Oxf. Dev. Stud. 2010, 38, 391-410. [CrossRef]

44. Atkinson, R.; Klausen, J.E. Understanding sustainability policy: Governance, knowledge and the search for integration. J. Environ. Policy Plan. 2011, 13, 231-251. [CrossRef]

45. Bassem, B.S. Governance and performance of microfinance institutions in Mediterranean countries. J. Bus. Econ. Manag. 2009, 10, 31-43. [CrossRef]

46. Bhatta, G.; Gonzalez, J.L. On Governing and Milking Cows: Replicating Good Governance Practices from East Asia. Asian J. Public Adm. 2014, 20, 123-150. [CrossRef]

47. Van Doeveren, V. Rethinking Good Governance. Public Integr. 2011, 13, 301-318. [CrossRef]

48. Kurucz, E.C.; Colbert, B.A.; Lüdeke-Freund, F.; Upward, A.; Willard, B. Relational leadership for strategic sustainability: Practices and capabilities to advance the design and assessment of sustainable business models. J. Clean. Prod. 2017, 140, 189-204. [CrossRef]

49. Da Rosa, L.A.B.; Kneipp, J.M.; Bichueti, R.S.; Gomes, C.M.N.; Zamberlan, J.F. The Innovation Process and the Development of a Sustainability Strategy. Lat. Am. Bus. Rev. 2013, 14, 289-308. [CrossRef]

50. Edgeman, R.; Eskildsen, J. Viral innovation: Integration via sustainability and enterprise excellence. J. Innov. Bus. Best Pract. 2012, 2012, 13. [CrossRef]

51. Anttila, J.; Jussila, K. An advanced insight into managing business processes in practice. Total Qual. Manag. Bus. Excell. 2013, 24, 918-932. [CrossRef]

52. Neely, A.; Mills, J.; Platts, K.; Richards, H.; Gregory, M.; Bourne, M.; Kennerley, M. Performance measurement system design: Developing and testing a process-based approach. Int. J. Oper. Prod. Manag. 2000, 20, 1119-1145. [CrossRef] 
53. Kettinger, W.J.; Teng, J.T.; Guha, S. Business process change: A study of methodologies, techniques, and tools. MIS Q. 1997, 21, 55-80. [CrossRef]

54. Chancé, E.; Derrible, S.; Ashton, W.S. The need to adapt sustainability audits to atypical business models. Clean Technol. Environ. Policy 2018, 20, 1113-1118. [CrossRef]

55. Looy, A.V.; Backer, M.D.; Poels, G. A conceptual framework and classification of capability areas for business process maturity. Enterp. Inf. Syst. 2014, 8, 188-224. [CrossRef]

56. Cavaco, S.; Crifo, P. CSR and financial performance: Complementarity between environmental, social and business behaviours. Appl. Econ. 2014, 46, 3323-3338. [CrossRef]

57. Chaudary, S.; Zafar, S.; Salman, M. Does total quality management still shine? Re-examining the total quality management effect on financial performance. Total. Qual. Manag. Bus. Excell. 2015, 26, 811-824. [CrossRef]

58. Erwin, D. Changing Organizational Performance: Examining the Change Process. Hosp. Top. 2009, 87, $28-40$. [CrossRef] [PubMed]

59. Minnis, W.; Elmuti, D. Organizational Effectiveness and Financial Performance: A Healthcare Study. J. Hosp. Mark. Public Relat. 2008, 18, 115-134. [CrossRef] [PubMed]

60. Gray, R. Does sustainability reporting improve corporate behaviour?: Wrong question? Right time? Account. Bus. Res. 2006, 36, 65-88. [CrossRef]

61. Guercini, S. Profiting from Creative Performance and Business Models over Time. Int. Stud. Manag. Organ. 2014, 44, 26-42. [CrossRef]

62. Alberti, F.G.; Varon Garrido, M.A. Can profit and sustainability goals co-exist? New business models for hybrid firms. J. Bus. Strategy 2017, 38, 3-13. [CrossRef]

63. Maltz, E.; Bi, H.H.; Bateman, M. Benchmarking sustainability performance: The next step in building sustainable business models. J. Public Aff. 2018, 18, 1606. [CrossRef]

64. Kavanagh, D.; Lightfoot, G.; Lilley, S. Finance past, finance future: A brief exploration of the evolution of financial practices. Manag. Organ. Hist. 2014, 9, 135-149. [CrossRef]

65. Kristensen, K.; Westlund, A.H. Accountable Business Performance Measurement for Sustainable Business Excellence. Total. Qual. Manag. Bus. Excell. 2004, 15, 629-643. [CrossRef]

66. Skare, M.; Golja, T. Corporate Social Responsibility and Corporate Financial Performance-Is There A Link? Econ. Res. 2012, 25, 215-242. [CrossRef]

67. Shrivastava, P.; Berger, S. Sustainability principles: A review and directions. Organ. Manag. J. 2010, 7, 246-261. [CrossRef]

68. Sebastiani, R.; Corsaro, D.; Montagnini, F.; Caruana, A. Corporate sustainability in action. Serv. Ind. J. 2014, 34, 584-603. [CrossRef]

69. Brundtland, G.; Khalid, M.; Agnelli, S.; Al-Athel, S.; Chidzero, B.; Fadika, L.; de Botero, M.M. Our Common Future ('Brundtland Report'); Oxford University Press: Oxford, UK, 1987.

70. Garvare, R.; Johansson, P. Management for sustainability-A stakeholder theory. Total Qual. Manag. Bus. Excell. 2010, 21, 737-744. [CrossRef]

71. Eskildsen, J.; Edgeman, R. Continuous relevance \& responsibility: Integration of sustainability \& excellence via innovation. J. Posit. Manag. 2012, 3, 67-81.

72. Davies, A. Achieving sustainability in manufacturing via organisational and operational learning. Int. J. Sustain. Eng. 2012, 5, 135-144. [CrossRef]

73. Ferdig, M.A. Sustainability Leadership: Co-creating a Sustainable Future. J. Chang. Manag. 2007, 7, $25-35$. [CrossRef]

74. Harik, R.; El Hachem, W.; Medini, K.; Bernard, A. Towards a holistic sustainability index for measuring sustainability of manufacturing companies. Int. J. Prod. Res. 2015, 53, 4117-4139. [CrossRef]

75. Molnar, E.; Mulvihill, P.R. Sustainability-focused Organizational Learning: Recent Experiences and New Challenges. J. Environ. Plan. Manag. 2003, 46, 167-176. [CrossRef]

76. Husgafvel, R.; Pajunen, N.; Virtanen, K.; Paavola, I.-L.; Päällysaho, M.; Inkinen, V.; Ekroos, A. Social sustainability performance indicators-Experiences from process industry. Int. J. Sustain. Eng. 2015, 8, 14-25. [CrossRef]

77. Dervitsiotis, K. The pursuit of sustainable business excellence: Guiding transformation for effective organizational change. Total Qual. Manag. Bus. Excell. 2003, 14, 251-267. [CrossRef]

78. Schaltegger, S.; Lüdeke-Freund, F.; Hansen, E.G. Business cases for sustainability: The role of business model innovation for corporate sustainability. Int. J. Innov. Sustain. Dev. 2012, 6, 95-119. [CrossRef] 
79. Bayer, S.; Gann, D. Innovation and the dynamics of capability accumulation in project-based firms. Innovation 2007, 9, 217-234. [CrossRef]

80. Cavaco, N.M.; Machado, V.C. Sustainable competitiveness based on resilience and innovation-An alternative approach. Int. J. Manag. Sci. Eng. Manag. 2015, 10, 155-164. [CrossRef]

81. Dervitsiotis, K.N. A framework for the assessment of an organisation's innovation excellence. Total Qual. Manag. Bus. Excell. 2010, 21, 903-918. [CrossRef]

82. Maletič, M.; Maletič, D.; Dahlgaard, J.J.; Dahlgaard-Park, S.M.; Gomišček, B. Effect of sustainability-oriented innovation practices on the overall organisational performance: An empirical examination. Total Qual. Manag. Bus. Excell. 2016, 27, 1171-1190. [CrossRef]

83. Dervitsiotis, K.N. The challenge of adaptation through innovation based on the quality of the innovation process. Total Qual. Manag. Bus. Excell. 2011, 22, 553-566. [CrossRef]

84. Ganapathy, S.P.; Natarajan, J.; Gunasekaran, A.; Subramanian, N. Influence of eco-innovation on Indian manufacturing sector sustainable performance. Int. J. Sustain. Dev. World Ecol. 2014, 21, 198-209. [CrossRef]

85. Hervas-Oliver, J.-L.; Sempere-Ripoll, F.; Boronat-Moll, C.; Rojas, R. Technological innovation without R\&D: Unfolding the extra gains of management innovations on technological performance. Technol. Anal. Strat. Manag. 2015, 27, 19-38. [CrossRef]

86. Bolton, R.; Hannon, M. Governing sustainability transitions through business model innovation: Towards a systems understanding. Res. Policy 2016, 45, 1731-1742. [CrossRef]

87. Sergeeva, N. Understanding of labelling and sustaining of innovation in construction: A sensemaking perspective. Eng. Proj. Organ. J. 2014, 4, 31-43. [CrossRef]

88. Gurbuz, S.; Mert, I.S. Impact of the strategic human resource management on organizational performance: Evidence from Turkey. Int. J. Hum. Resour. Manag. 2011, 22, 1803-1822. [CrossRef]

89. Jabbour, C.J.C.; Santos, F.C.A. The central role of human resource management in the search for sustainable organizations. Int. J. Hum. Resour. Manag. 2008, 19, 2133-2154. [CrossRef]

90. Zaugg, R.; Thom, N. Excellence through implicit competencies: Human resource managementOrganisational development-Knowledge creation. J. Chang. Manag. 2002, 3, 199-211. [CrossRef]

91. Brown, A. How do excellent companies stay excellent? Total Qual. Manag. Bus. Excell. 2013, 24, 108-118. [CrossRef]

92. Anderson, V.; Garavan, T.; Sadler-Smith, E. Corporate social responsibility, sustainability, ethics and international human resource development. Hum. Resour. Dev. Int. 2014, 17, 497-498. [CrossRef]

93. Briggs, S.; Keogh, W. Integrating human resource strategy and strategic planning to achieve business excellence. Total Qual. Manag. 1999, 10,447-453. [CrossRef]

94. Costantini, V.; Monni, S. Sustainable Human Development for European Countries. J. Hum. Dev. 2005, 6, 329-351. [CrossRef]

95. Zink, K.J. The contribution of quality of work to organisational excellence. Total Qual. Manag. Bus. Excell. 2011, 22, 567-585. [CrossRef]

96. Debrah, Y.A.; Ofori, G. Human resource development of professionals in an emerging economy: The case of the Tanzanian construction industry. Int. J. Hum. Resour. Manag. 2006, 17, 440-463. [CrossRef]

97. Edgeman, R.; Hammond, S.; Keller, C.; McGraw, J. Virtuous cycles: Organizational dynamics of innovation and excellence. Total Qual. Manag. Bus. Excell. 2018, 29, 1-17. [CrossRef]

98. Edgeman, R.L.; Fraley, L.A. A system of profound consciousness: Building beyond Deming. Total Qual. Manag. 2008, 19, 683-707. [CrossRef]

99. Rohrbaugh, J. Improving the quality of group judgment: Social judgment analysis and the nominal group technique. Organ. Behav. Hum. Perform. 1981, 28, 272-288. [CrossRef]

100. Guenther, E.; Saling, P. Supporting industrial decision-making by sustainability performance measurement: Bridging the gaps between sustainability performance research and sustainability performance management in industry. Environ. Sustain. Manag. Account. Netw. 2015, 1, 38-39.

(C) 2018 by the authors. Licensee MDPI, Basel, Switzerland. This article is an open access article distributed under the terms and conditions of the Creative Commons Attribution (CC BY) license (http:/ / creativecommons.org/licenses/by/4.0/). 